\title{
Machine prediction of US imports from the PRC in the context of mutual sanctions
}

\author{
Petr Šuler̆ $^{*}$, Jan Mareček ${ }^{1}$ \\ ${ }^{1}$ Institute of Technology and Business, School of Expertness and Valuation, Okružní 517/10, 37001 \\ České Budějovice, Czech Republic
}

\begin{abstract}
The aim of this paper is to mechanically predict the import of the United States of America (USA) from the People's Republic of China (PRC). The trade restrictions of the USA and the PRC caused by the USA feeling of imbalance of trade between the two states have significantly influenced not only the trade between the two players, but also the overall climate of international trade. The result of this paper is the finding that multilayer perceptron networks (MLP) appear to be an excellent tool for predicting USA imports from the PRC. MLP networks can capture both the trend of the entire time series and its seasonal fluctuations. It also emerged that time series delays need to be applied. Acceptable results are shown to delay series of the order of 5 and 10 months. The mutual sanctions of both countries did not have a significant impact on the outcome of the machine learning prediction.
\end{abstract}

Key words: machine prediction, trade war, sanctions, international trade

\section{Introduction}

The business relationship between the USA and China is currently supported by roughly 2.6 million jobs in a large number of industrial sectors including jobs which Chinese corporations have created in the USA [1]. Since Chinese middle class will go on developing in the next decade, American corporations will have the opportunity to benefit from a new and lucrative consumer basecamp which may further encourage the employment and economic growth [2]. A big advantage to the US economy in going into business with China is that China has become an integral part of the global production supply chain; a considerable part of its export includes components produced abroad and provided for the final assembly in China [3]. If the value of these imported components is subtracted from Chinese export, the business deficit between the USA and China will be reduced by a half to roughly $1 \%$ of GNP. The next big advantage is the expectation that China will remain one of the fastest growing strong economies and will be creating ample opportunities for the growth of the US society; supposing that China will continue in economic improvements which will remove existing obstacles to the easy access to the market in a large number of sectors [4].

\footnotetext{
*Corresponding author: petr.suler@,cez.cz
} 
According to Chossudovsky [5] China is not dependent on the import from the USA. On the contrary, the USA strongly relies on the import from China which means that the US economy is weak in regard to industry and production. As a matter of fact, "Made in China" is a backbone of the majority of retails in the USA. These retails strongly encourage domestic consumption in all distinct categories of goods - clothes, shoes, hardware, electronics, toys, jewellery, household needs, food, TV, mobile phones etc. "Made in China" is an excellent source of profit and wealth in the USA since consumer commodities imported from low-wage Chinese economy are often sold in retails for more than a tenfold price of their production costs [6].

At the end of 2018 and in the first half of 2019 the business rivalry between PRC and the USA had a deep impact on Chinese ideologies and politics, social-economic and military development and its foreign policy [7].

The "business war" between China and the USA was one of the most important international economic events in 2018. The USA and China are the two soundest global economies which means that the current business war between the USA and China also influences other economies in the world $[8,9]$. Owing to the Chinese crucial role in the global economy and geopolitical impacts, the USA referred to China as a competitor of the strategy [10] and considered China as a grave threat to American security interests. The fact that China was officially marked and treated as a major threat to the US national interests had catastrophic consequences for the USA and the rest of the world [11].

Itakura [12] assesses the impact of the business war between the USA and China using a model of global business with dynamic calculation general equality (CGE). The author carries out a simulation analysis ex ante and analyses three scenarios in order to understand the way the business war influences tariffs, investments and productivity. The escalation of the business war reduces the gross national product (GNP) in China by $-1.41 \%$ and in the USA by $-1.35 \%$. The business war reduces almost the entire sectoral import and outputs in the both countries. The author provided the dynamic model CGE with requirements for the import and analyses the difference between the results of both models concerning impacts of the business war on GNP and the bilateral trade.

Chong and Li [13] summarize the key ideas of Trump's administration which stands behind Chines-American business war. For example, Trump believes that the bilateral trade deficit between the USA and China jeopardizes American interests. He argues that the main cause of the bilateral deficit lies in unfair export Chinese subventions and high tariffs as contrasted to the American import. The only way for the USA to reduce the bilateral deficit is to impose high tariffs on Chinese products. The bilateral trade inequality does not actually threaten the US economy since Chinese investors invest back in the USA and use means from the bilateral trade surplus. The convenient way how to resolve ChineseAmerican trade inequality would be to increase Chinese imports and to persuade the USA to lift the restriction on exporting advanced technologies to China and that the both countries should overcome mutual bilateral trade obstacles.

The recent figures have shown that the USA frequently imposes economic sanctions. The sanctions, though, usually do not meet the intended political or economic goals [14]. Li [15] gives an example of the cultural differences. Cultural standards of the target countries play an important role in determining the effectiveness of the sanctions. Using examples of American economic sanctions against China, the author demonstrates that the standards and beliefs of the target countries play an essential role in assessing the effectiveness of the imposed sanctions. The result of the study is that initiators of economic sanctions should take into account the cultural responsibility and sensitivity of goals in order to impose legal and effective economic sanctions as an appropriate means of foreign policy.

The USA has imposed a large scale of economic sanctions starting from export controls up to orders to specific imports. Yang et al. [16] found out that although American 
sanctions did not have a significant devastating impact on the overall Chinese economic growth and trade between the both countries with respect to macro economy, the sanctions have a damaging impact on the producer and consumer in both countries. The US economic sanctions prevented the import of technologies to China. American restrictions on the import from China caused dead weight costs for the USA as a result of higher domestic production costs of import substitutes. American export controls inhibited the export from the USA to China and contributed to huge trade deficits between the USA and China. Export controls also caused losses of highly paid jobs in the USA. Moreover, the US economic sanctions against China also had significant impacts on the third party. Chinese diversification of import to sources other than the USA may have a long-term impact on the export from the USA to China even though American economic sanctions against China will be lifted.

China declared to impose sanctions on American corporations involved in the agreement to sell tanks, rockets and other related equipment equal to 2.2 billion dollars to Thai-wan; China proclaimed that this act had violated Chinese sovereignty and national security. The spokesman of Chinese Ministry of Foreign Affairs Geng Shuang said that the USA having sold the weapons presents "a serious violation of the international law and regulations governing international relationships". In order for China to defend its national interests, the country will impose sanctions on American corporations involved in the above-mentioned sale of weapons to Tchai-wan [17].

In September 2018 American president Donald Trump announced the imposition of tenper cent tariff on the import of products from China. However, Trump also threatened to increase the tariff to $25 \%$ as of the following year. China promptly responded by a plan aiming at punitive measures in the sector of fiscal and monetary policy [18]. The monetary policy can thereby expect growing pressure on depreciating Chinese currency with the intent to compensate for the consequences of the measures. This will be implemented by mere verbal interventions or a foreign-exchange intervention of the central bank. The fiscal policy will most likely see other punitive measures [19].

Perhaps American president Donald Trump has just done a great favour to SouthKorean electronics, which became Samsung after he had blocked Chinese Huawei, which the president accuses of helping Peking with its spying activities. The main American suppliers of Huawei Corporation allegedly stated that they would immediately disrupt the supplies of the Chinese corporation. In addition, Google added fuel to the flames as it stated that it would block the use of some of Huawei's services and applications for Android on its devices. As Trump had put Huawei on the black list of American technological businesses, he effectively banned Huawei from producing smartphones and tablets to sale outside China and to sell its laptops elsewhere [20].

Besedeš and Prusa [21] estimated impacts of the reduction of anti-dumping tariffs according to the probit model of random outcomes. Their research demonstrated that effects of anti-dumping tariffs which the USA imposed on the trade are under a careful examination and provisional decision and they are even more visible than after the final decision would have been reached. They also found out that for the target countries it is hard to recover lost trade level after the anti-dumping tariff has been abolished. Lee [22] compared the effects of import reduction with the target countries and the effects after the third country has abused the import policy. It demonstrates that anti-dumping tariffs have import-restricting effects. Park [23] in his works analysed the influence of anti-dumping tariffs on import studying Chinese data from 2002 to 2004 using Generalized Method of Moments (GMM). The results show that the anti-dumping protection has far-reaching effects on the inhibition and deflection of the trade.

Choi [24] analysed effects of anti-dumping measures on imports with the intent to find out whether the effect of reducing anti-dumping tariff on the business is principal. Author's 
results suggest that the increase of anti-dumping tariff by $1 \%$ reduces the import of the target product roughly by 0.43 which corresponds to $0.51 \%$. However, exact figures show that the overall import of target products increased roughly by $30 \%$ while the anti-dumping tariff was legally effective. It means that anti-dumping tariff presents only a temporary relief from import schemes.

Yu, Wang and Lai [25] aim to devise a methodology that should consider seasonal fluctuations while equalizing time series through artificial neural networks giving the import from China to the USA as an example. The difficulty to predict the volume of foreign trade is often caused by restricting a lot of conventional prediction models. In order to boost the prognostic efficiency, it is necessary to develop a method which will hybridize econometric and artificial intelligence models [26].

According to the idea of non-linear prediction of the phase space reconstruction Weijin and Yuhui [27] presented a model of delays in time series of BP neural network; the model's ability to generalize was improved by Bayesian regularization. The model is used for predicting import and export trades in one sector. In comparison with a broad prognosis assessment, the authors concluded that non-linear prognosis may not only focus on data combinations and accuracy improvement, but it can also clearly reflect non-linear characteristics of the prognosis system.

\section{Data and methods}

The mutual trade restrictions between the USA and China arising from the feeling of the USA concerning the imbalance of the trade between the two countries have significantly influenced the trade between the countries in the recent years as well as the overall atmosphere in the international trade. The United States have decided to regulate trade by imposing duty on specific kinds of goods. This naturally creates an extraordinary situation in terms of the overall trade balance, import, and export. Given that the trade war has been started by the USA, it could be expected that the first variable to be influenced will be the US import from the China. Therefore, the time series of this variable will show extraordinary fluctuations. The information on the USA import from the China thus constitutes an important data set for time series related research.

The dataset illustrates the course of the time series at monthly intervals from January 2000 to July 2019. The course of the time series is shown in Figure 1.

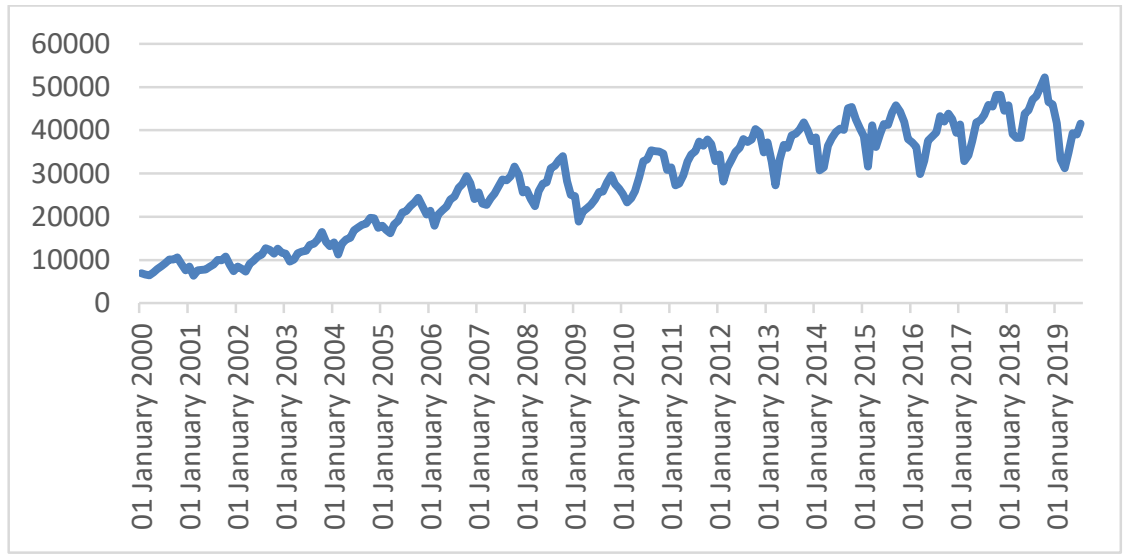

Fig. 1. Development of USA import from PRC between January 2000 and July 2019

Source: [28], own processing. 
Note: the values in the Table and in the entire text are given in billions of American dollars (USD).

The Figure clearly shows seasonal fluctuations within the individual years of the monitored period. There was an especially significant growth in import from USD $6902 \mathrm{bn}$. in October 2018. This means more than 7 times higher USA import from the PRC in the monitored period.

Table 1 shows the basic statistical characteristics of the dataset.

Table 1. Basic statistical characteristics of the examined dataset

\begin{tabular}{|l|r|r|r|r|}
\hline \multicolumn{1}{|c|}{ Statistics } & $\begin{array}{c}\text { Date (Input } \\
\text { variable) }\end{array}$ & $\begin{array}{c}\text { Month (Input } \\
\text { variable) }\end{array}$ & $\begin{array}{c}\text { Year (Input } \\
\text { variable) }\end{array}$ & $\begin{array}{c}\text { Import (Output } \\
\text { (target) })\end{array}$ \\
\hline Minimum (Training) & 36556.00 & 1.00000 & 2000.000 & 6375.60 \\
\hline Maximum (Training) & 43646.00 & 12.00000 & 2019.000 & 48127.80 \\
\hline Average (Training) & 40050.47 & 6.45455 & 2009.115 & 27572.76 \\
\hline Standard deviation (Training) & 2001.16 & 3.50688 & 5.473 & 12039.78 \\
\hline Minimum (Testing) & 36585.00 & 1.00000 & 2000.000 & 6584.40 \\
\hline Maximum (Testing) & 43677.00 & 12.00000 & 2019.000 & 52202.30 \\
\hline Average (Testing) & 40130.09 & 6.00000 & 2009.371 & 26146.36 \\
\hline Standard deviation (Testing) & 2418.96 & 3.38683 & 6.691 & 12282.23 \\
\hline Minimum (Validation) & 36646.00 & 1.00000 & 2000.000 & 7070.50 \\
\hline Maximum (Validation) & 43373.00 & 12.00000 & 2018.000 & 50015.00 \\
\hline Average (Validation) & 40412.86 & 6.71429 & 2010.086 & 29966.20 \\
\hline Standard deviation (Validation) & 3403.28 & 3.44159 & 9.284 & 21320.19 \\
\hline Minimum (Overall) & 36556.00 & 1.00000 & 2000.000 & 6375.60 \\
\hline Maximum (Overall) & 43677.00 & 12.00000 & 2019.000 & 52202.30 \\
\hline Average (Overall) & 40116.30 & 6.42553 & 2009.298 & 27716.79 \\
\hline Standard deviation (Overall) & 2069.19 & 3.45140 & 5.669 & 12057.45 \\
\hline
\end{tabular}

Source: Own processing.

There will be a regression carried out using neural structures. We will generate multilayer perceptron networks (MLP). Three sets of artificial neural networks will be generated. They will differ according to assumed time series lag:

1. 1-month lag,

2. 5-month lag,

3. 10-month lag.

Time series lag is the amount of data used to calculate the next value (that is in the first case, based on the value of one preceding month, and in the second case, based on five preceding values and in the third case, based on outputs of the previous 10 months). A larger time series lag can result from averaging values. A small lag can result in extreme fluctuations of equalized time series. Each time series lag is more challenging for the complexity of the artificial neural network structure, namely neurons in the input layer (the input layer of the neural network will have 3 neurons in experiment 1, and 15 neurons in experiment 2, and even 30 neurons in experiment 3 ). The other settings will be equal for each experiment. Time will be used as the continuous independent variable. Seasonal fluctuations will be represented by a category variable of the month and year in which the value was measured. Thus we will use possible monthly seasonal fluctuations of a time series. At the same time, we should capture the overall trend of a time series. US import from China will be used as a dependent variable. The time series will be divided into three sets - Training, Testing a Validation. The first set will comprise $70 \%$ input data. We will generate neural structures based on the Training set. We will leave $15 \%$ input information in the two remaining sets of data. Both sets will be used for reliability verification of the identified neural structure, or model. We will generate 10,000 neural networks. We will retain 5 of them that show the best characteristics. The least squares method will be used. 
The process of generating networks will be finished if no improvement is achieved, i.e. the sum of squares is not decreasing. Thus we will only retain those neural structures where the sum of residual squares to the actual US import from China is the lowest possible (ideally zero). A hidden layer will have at least two neurons, but no more than 8 for experiment 1 and 9 for experiments 2 and 3 . We will consider the following distribution functions in the hidden layer and in the output layer: Linear, Logistic, Atanh, Exponential, Sinus.

Other settings will remain default (according to the ANS tool - automated neural networks). In conclusion, we will compare results of the three completed experiments to determine whether the defined machine learning methodology is correct in terms of direction and to identify what time lag is closest to the correct result.

\section{Results}

\subsection{Experiment 1 (1-month lag of time series)}

Table 2 provides a summary of neural networks retained from Experiment no. 1.

Table 2. Neural networks retained from Experiment 1

\begin{tabular}{|l|l|c|c|c|c|c|c|c|c|c|}
\hline Network & $\begin{array}{c}\text { Training } \\
\text { perform. }\end{array}$ & $\begin{array}{c}\text { Testing } \\
\text { perform. }\end{array}$ & $\begin{array}{l}\text { Validation } \\
\text { perform. }\end{array}$ & $\begin{array}{c}\text { Training } \\
\text { error }\end{array}$ & $\begin{array}{c}\text { Testing } \\
\text { error }\end{array}$ & $\begin{array}{c}\text { Validation } \\
\text { error }\end{array}$ & $\begin{array}{c}\text { Training } \\
\text { algorithm }\end{array}$ & $\begin{array}{c}\text { Error } \\
\text { function }\end{array}$ & $\begin{array}{c}\text { Activation } \\
\text { of hidden } \\
\text { laver }\end{array}$ & $\begin{array}{c}\text { Output } \\
\text { activation } \\
\text { function }\end{array}$ \\
\hline $\begin{array}{l}\text { MLP } \\
3-7-1\end{array}$ & 0.990716 & 0.987123 & 0.990223 & 1302564 & 1880266 & 1381484 & $\begin{array}{c}\text { BFGS (Quasi- } \\
\text { Newton) 206 }\end{array}$ & $\begin{array}{c}\text { Sum of } \\
\text { squares }\end{array}$ & Tanh & Exponential \\
\hline MLP & 0.990497 & 0.991163 & 0.989850 & 1330314 & 1293691 & 1409508 & $\begin{array}{c}\text { BFGS (Quasi- } \\
\text { Newton) 334 }\end{array}$ & $\begin{array}{c}\text { Sum of } \\
\text { squares }\end{array}$ & Logistic & Identity \\
\hline $\begin{array}{l}\text { MLP } \\
3-4-1\end{array}$ & 0.986405 & 0.978384 & 0.990274 & 1916087 & 3442250 & 1383508 & $\begin{array}{c}\text { BFGS (Quasi- } \\
\text { Newton) } 81\end{array}$ & $\begin{array}{c}\text { Sum of } \\
\text { squares }\end{array}$ & Tanh & Exponential \\
\hline $\begin{array}{l}\text { MLP } \\
\text { 3-9-1 }\end{array}$ & 0.992081 & 0.984770 & 0.988757 & 1108202 & 2261257 & 1566143 & $\begin{array}{c}\text { BFGS (Quasi- } \\
\text { Newton) 240 }\end{array}$ & $\begin{array}{l}\text { Sum of } \\
\text { squares }\end{array}$ & Tanh & Sinus \\
\hline $\begin{array}{l}\text { MLP } \\
\text { 3-4-1 }\end{array}$ & 0.983507 & 0.977995 & 0.988989 & 2308896 & 3318420 & 1546956 & $\begin{array}{c}\text { BFGS (Quasi- } \\
\text { Newton) 74 }\end{array}$ & $\begin{array}{l}\text { Sum of } \\
\text { squares }\end{array}$ & Tanh & Exponential \\
\hline
\end{tabular}

Source: Own processing.

The table shows that neural networks with 4 to 9 neurons in the hidden layer were retained. The hyperbolic tangent function and the logistic function are used neural networks to activate the hidden layer. The output neuron layer is activated by the exponential, identity and sinus functions. Of course, the performance of neural networks is important. It is expressed by a correlation coefficient. The correlation coefficient is very high for all data sets and all networks, each time above 0.98 which is a high level of direct dependence. This parameter clearly shows that the retained neural structures constitute a highly credible model of a real time series, thus being able to truly predict future observations.

Figure 2 provides a comparison of the actual course of time series and equalized times series. 


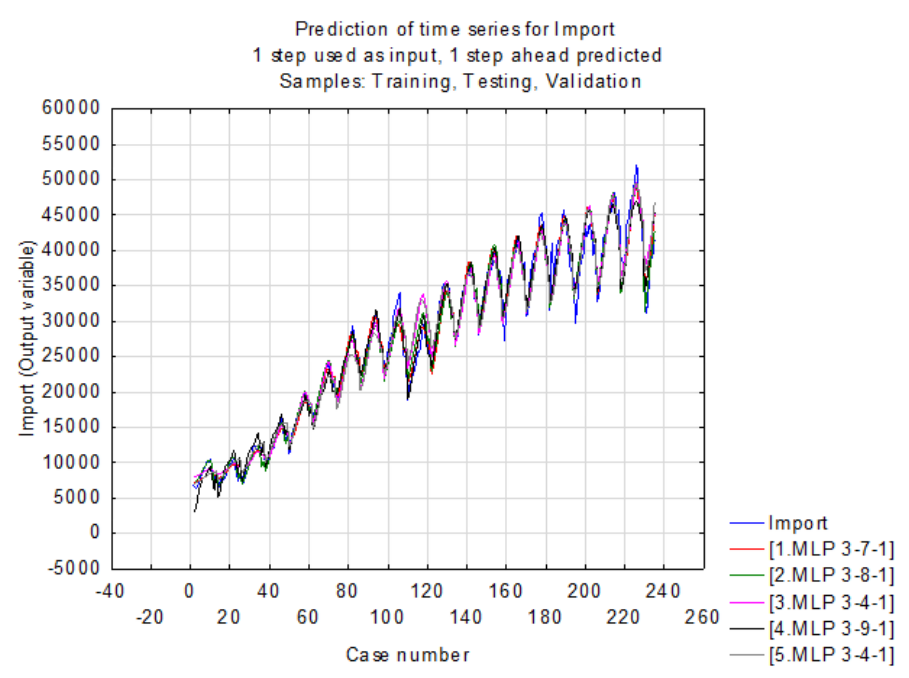

Fig. 2. Equalized time series of retained networks - Experiment 1

Source: Own processing.

It is also obvious from Figure 2 that all equalized times series are able to copy fairly well the course of the actual US import from China. Except for minor exceptions, each can not only capture the trend but even seasonal fluctuations. In order to establish whether networks are applicable or not, we will further examine their use in forecasting. We will predict the US import from China in the period of August 2019 to December 2020. The details are shown in Table 3.

Table 3. Forecast for the period of August 2019 to January 2020 by networks retained from Experiment 1

\begin{tabular}{|l|r|r|r|r|r|}
\hline \multicolumn{1}{|c|}{ Date } & MLP 3-7-1 & MLP 3-8-1 & MLP 3-4-1 & MLP 3-9-1 & MLP 3-4-1 \\
\hline August 31, 2019 & 47645.49 & 44936.4 & 47610.17 & 46645.94 & 49518.71 \\
\hline September 30, 2019 & 49591.31 & 45182.8 & 50658.15 & 47420.89 & 52071.62 \\
\hline October 31, 2019 & 49830.61 & 44064.5 & 52774.70 & 47654.44 & 53358.01 \\
\hline November 30, 2019 & 48105.30 & 40009.4 & 52639.24 & 47142.82 & 53452.82 \\
\hline December 31, 2019 & 45781.00 & 32482.2 & 51014.06 & 45928.15 & 52533.93 \\
\hline January 31, 2020 & 45205.55 & 28064.1 & 51886.42 & 45578.78 & 50978.39 \\
\hline February 29, 2020 & 35279.15 & -7220.4 & 40595.24 & 35745.96 & 41307.45 \\
\hline March 31, 2020 & 36688.44 & -9904.3 & 41939.51 & 38287.74 & 42220.96 \\
\hline April 30, 2020 & 38417.74 & -12631.8 & 43544.56 & 41572.72 & 44126.79 \\
\hline May 31, 2020 & 40511.25 & -14734.2 & 45528.36 & 44750.52 & 47153.75 \\
\hline June 30, 2020 & 42970.47 & -16560.3 & 48111.26 & 46893.48 & 51335.50 \\
\hline July 31, 2020 & 45675.86 & -17818.6 & 51489.89 & 47835.32 & 56252.61 \\
\hline August 31, 2020 & 48253.33 & -18925.5 & 55844.60 & 48096.97 & 61195.95 \\
\hline September 30, 2020 & 49959.83 & -20026.7 & 60906.72 & 48127.50 & 65250.80 \\
\hline October 31, 2020 & 49898.49 & -21814.3 & 65370.34 & 48126.36 & 67751.33 \\
\hline November 30, 2020 & 47926.08 & -26244.6 & 67291.30 & 47998.17 & 68617.90 \\
\hline December 31, 2020 & 45552.30 & -33683.7 & 67273.08 & 47393.27 & 67992.91 \\
\hline
\end{tabular}

Source: Own processing. 
It is apparent at first sight that network 2. MLP 3-8-1 gives a senseless prediction of the variable under review. It even shows negative values of import. However, this is not possible in real world. There is a less difference between the others. Therefore, we will use Figure 3 (Time series and forecasting trend) to choose the most successful neural network.

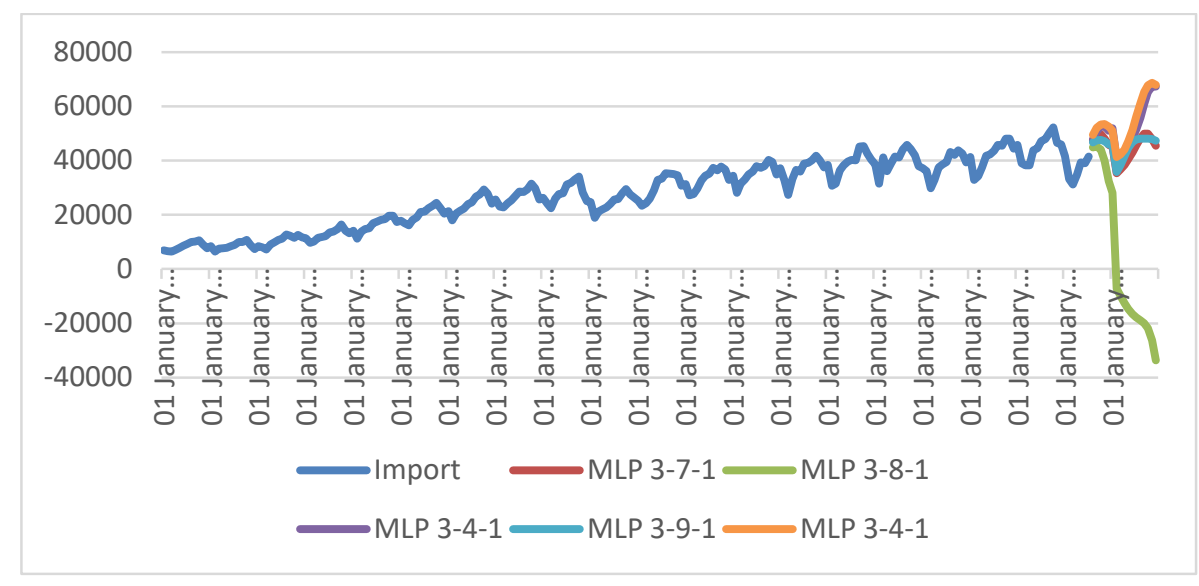

Fig. 3. Time series and forecasting trend by networks retained from Experiment 1

Source: Own processing.

Now the expert estimation comes into play. As a result, 1. MLP 3-7-1 and 4. MLP 3-9-1 networks are identified as close to the correct result. Considering the statistics of equalized time series, I conclude that 4. MLP 3-9- 1 is the most successful and most accurate artificial neural network.

\subsection{Experiment 2 (5-month lag of time series)}

Table 4 provides a summary of neural networks retained from Experiment no. 2 where 5month lag of time series is expected.

Table 4. Neural networks retained from Experiment 2

\begin{tabular}{|c|c|c|c|c|c|c|c|c|c|c|}
\hline Network & \begin{tabular}{|c|} 
Training \\
perform.
\end{tabular} & $\begin{array}{r}\text { Testing } \\
\text { perform. }\end{array}$ & $\begin{array}{l}\text { Valid. } \\
\text { perform. }\end{array}$ & $\begin{array}{c}\text { Training } \\
\text { error }\end{array}$ & $\begin{array}{c}\text { Testing } \\
\text { error }\end{array}$ & $\begin{array}{l}\text { Valid. } \\
\text { error }\end{array}$ & $\begin{array}{l}\text { Training } \\
\text { algorithm }\end{array}$ & $\begin{array}{c}\text { Error } \\
\text { function }\end{array}$ & $\begin{array}{c}\text { Activation } \\
\text { of hidden } \\
\text { layer }\end{array}$ & $\begin{array}{c}\text { Output } \\
\text { activation } \\
\text { function }\end{array}$ \\
\hline \begin{tabular}{|l|} 
MLP \\
$15-3-1$
\end{tabular} & 0.984886 & 0.969392 & 0.985259 & 2049185 & 3621980 & 1610485 & \begin{tabular}{|c|} 
BFGS (Quasi- \\
Newton) 64
\end{tabular} & $\begin{array}{c}\text { Sum of } \\
\text { squares }\end{array}$ & Logistic & Identity \\
\hline \begin{tabular}{|l|} 
MLP \\
$15-7-1$ \\
\end{tabular} & 0.991430 & 0.979645 & 0.987889 & 1152035 & 2003906 & 1290950 & \begin{tabular}{|l} 
BFGS (Quasi- \\
Newton) 148 \\
\end{tabular} & $\begin{array}{c}\text { Sum of } \\
\text { squares }\end{array}$ & Tanh & Exponential \\
\hline \begin{tabular}{|l|} 
MLP \\
$15-7-1$ \\
\end{tabular} & 0.989698 & 0.977635 & 0.986896 & 1390544 & 2312432 & 1461439 & \begin{tabular}{|l|} 
BFGS (Quasi- \\
Newton) 114 \\
\end{tabular} & $\begin{array}{l}\begin{array}{l}\text { Sum of } \\
\text { squares }\end{array} \\
\end{array}$ & Tanh & Exponential \\
\hline $\begin{array}{l}\text { MLP } \\
15-10-1 \\
\end{array}$ & 0.989664 & 0.977584 & 0.985530 & 1397550 & 2337306 & 1638214 & \begin{tabular}{|l|} 
BFGS (Quasi- \\
Newton) 150
\end{tabular} & $\begin{array}{c}\text { Sum of } \\
\text { squares }\end{array}$ & Tanh & Exponential \\
\hline \begin{tabular}{|l|} 
MLP \\
$15-4-1$ \\
\end{tabular} & 0.982478 & 0.965299 & 0.985481 & 2377804 & 4413279 & 1725236 & \begin{tabular}{|c|} 
BFGS (Quasi- \\
Newton) 34 \\
\end{tabular} & $\begin{array}{l}\begin{array}{l}\text { Sum of } \\
\text { squares }\end{array} \\
\end{array}$ & Tanh & Exponential \\
\hline
\end{tabular}

Source: Own processing.

There are 15 neurons in the output layer with respect to the time series lag. The table shows that neural networks with 4 to 10 neurons in the hidden layer were retained. The hyperbolic tangent function and the logistic function are used by neural networks to activate the hidden layer. The output neuron layer is activated by the exponential function and the identity function. The correlation coefficient is very high for all data sets and all networks, 
each time above 0.96 which is a high level of direct dependence. This parameter clearly shows that the retained neural structures constitute a highly credible model of real time series, thus being able to truly predict future observations. The sum of least squares was used to establish the error rate. Even the error is acceptable with a view to input data (for all networks and sets).

Figure 4 provides a comparison of the actual course of time series and equalized times series.

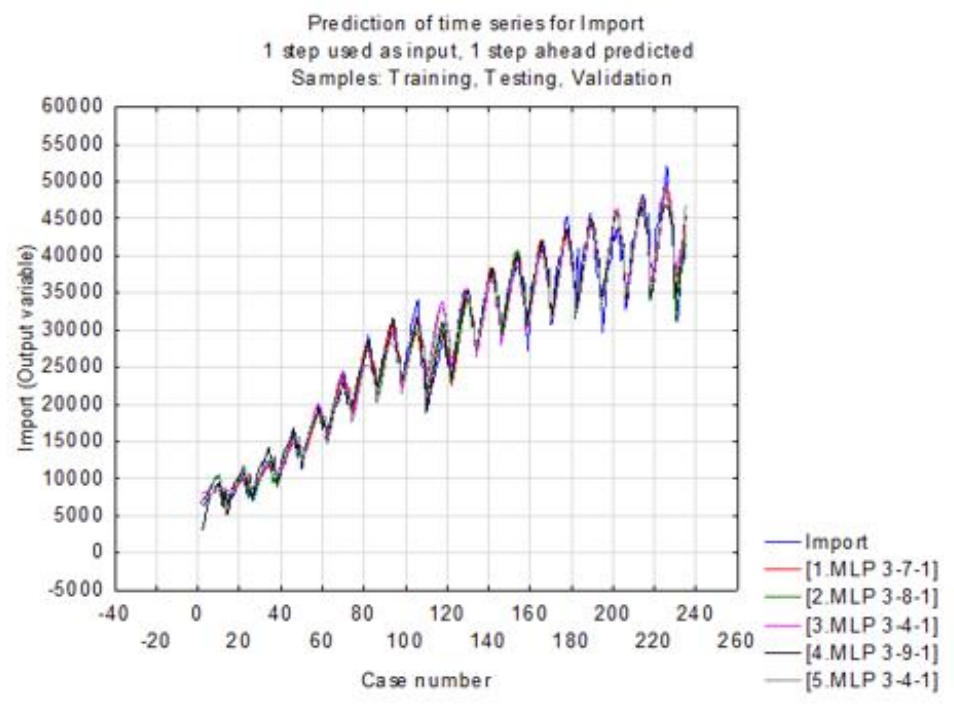

Fig. 4. Equalized time series of networks retained from Experiment 2

Source: Own processing.

It is also obvious from Figure 4 that all equalized times series are able to copy fairly well the course of the actual US import from China. Except for minor exceptions, each can not only capture the trend but even seasonal fluctuations.

In order to establish whether networks are applicable or not, we will further examine their use in forecasting. We will predict the US import from China in the period of August 2019 to December 2020. The details are shown in Table 5. 
Table 5. Forecast for the period of August 2019 to January 2020 by networks retained from Experiment 2

\begin{tabular}{|l|r|r|r|r|r|}
\hline \multicolumn{1}{|c|}{ Date } & MLP 15-3-1 & MLP 15-7-1 & MLP 15-7-1 & MLP 15-10- & MLP 15-4-1 \\
\hline August 31, 2019 & 47515.57 & 47002.25 & 47040.21 & 48861.78 & 47797.37 \\
\hline September 30, & 49604.57 & 49351.12 & 49124.91 & 51588.14 & 49334.92 \\
\hline October 31, 2019 & 50764.12 & 51231.68 & 51143.95 & 52961.69 & 50106.41 \\
\hline November 30, & 51112.63 & 50454.89 & 50574.42 & 50755.99 & 50462.89 \\
\hline December 31, & 50848.47 & 47639.46 & 47206.94 & 46915.98 & 50694.26 \\
\hline January 31, 2020 & 50248.03 & 48216.25 & 48999.36 & 46650.57 & 50964.55 \\
\hline February 29, 2020 & 44783.80 & 35272.04 & 38268.77 & 34983.18 & 45836.01 \\
\hline March 31, 2020 & 42825.99 & 35552.70 & 35592.07 & 37866.55 & 45078.61 \\
\hline April 30, 2020 & 41978.92 & 41250.17 & 39894.06 & 42639.63 & 43639.14 \\
\hline May 31, 2020 & 44659.23 & 43842.69 & 44274.29 & 43010.50 & 43976.81 \\
\hline June 30, 2020 & 44337.75 & 47957.59 & 49797.58 & 45170.13 & 44301.28 \\
\hline July 31, 2020 & 47481.72 & 51221.00 & 53123.88 & 52357.95 & 47687.89 \\
\hline August 31, 2020 & 50947.31 & 54986.77 & 56840.84 & 59182.85 & 51304.98 \\
\hline September 30, & 54119.11 & 59020.77 & 61001.23 & 65061.23 & 54268.33 \\
\hline October 31, 2020 & 56519.55 & 62076.98 & 65109.56 & 67830.92 & 56228.17 \\
\hline November 30, & 58001.95 & 60949.66 & 64774.65 & 64240.15 & 57365.47 \\
\hline December 31, & 58675.62 & 57821.82 & 61761.25 & 59256.33 & 57994.40 \\
\hline
\end{tabular}

Source: Own processing.

The results shown in the table represent a potential trend of the time series. It is warranted to a certain extent by the chart in Figure 5.

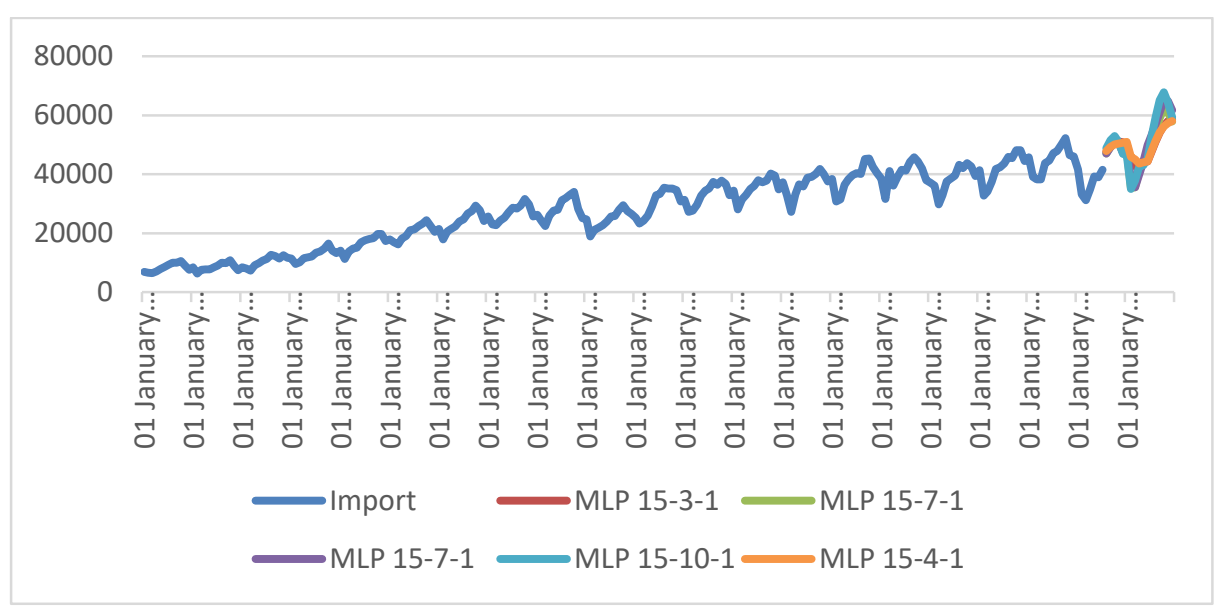

Fig. 5. Time series and forecasting trend by networks retained from Experiment 2

Source: Own processing.

If the actual trend of US import from China is compared to the expected time trend of the variable predicted by using the artificial neural networks retained from Experiment 2, we conclude (mainly considering the statistics table in Schedule 2) that 5. MLP 15-4-1 network is the best evaluated artificial neural structure. 


\subsection{Experiment 3 (10-month lag of time series)}

There were 10,000 artificial neural networks again generated for Experiment no. 3 and five with the best characteristics were retained (more details in Table 6).

Table 6. Neural networks retained from Experiment 1

\begin{tabular}{|l|l|l|l|l|l|l|l|c|c|c|}
\hline Network & $\begin{array}{l}\text { Training } \\
\text { perform. }\end{array}$ & $\begin{array}{c}\text { Testing } \\
\text { perform. }\end{array}$ & $\begin{array}{c}\text { Validation } \\
\text { perform. }\end{array}$ & $\begin{array}{c}\text { Training } \\
\text { error }\end{array}$ & $\begin{array}{c}\text { Testing } \\
\text { error }\end{array}$ & $\begin{array}{c}\text { Validation } \\
\text { error }\end{array}$ & $\begin{array}{c}\text { Training } \\
\text { algorithm }\end{array}$ & $\begin{array}{c}\text { Error } \\
\text { function }\end{array}$ & $\begin{array}{c}\text { Activation } \\
\text { of hidden } \\
\text { layer }\end{array}$ & $\begin{array}{c}\text { Output } \\
\text { activation } \\
\text { function }\end{array}$ \\
\hline $\begin{array}{l}\text { MLP } \\
30-3-1\end{array}$ & 0.982807 & 0.963986 & 0.987057 & 1875805 & 4873910 & 1391464 & $\begin{array}{c}\text { BFGS (Quasi- } \\
\text { Newton) 56 }\end{array}$ & $\begin{array}{c}\text { Sum of } \\
\text { squares }\end{array}$ & Tanh & Exponential \\
\hline $\begin{array}{l}\text { MLP } \\
30-3-1\end{array}$ & 0.980938 & 0.967076 & 0.985988 & 2113288 & 4195384 & 1524165 & $\begin{array}{c}\text { BFGS (Quasi- } \\
\text { Newton) 27 }\end{array}$ & $\begin{array}{c}\text { Sum of } \\
\text { squares }\end{array}$ & Tanh & Exponential \\
\hline $\begin{array}{l}\text { MLP } \\
30-3-1\end{array}$ & 0.981791 & 0.962650 & 0.985991 & 2000410 & 4995097 & 1514516 & $\begin{array}{c}\text { BFGS (Quasi- } \\
\text { Newton) 26 }\end{array}$ & $\begin{array}{c}\text { Sum of } \\
\text { squares }\end{array}$ & Tanh & Identity \\
\hline $\begin{array}{l}\text { MLP } \\
30-4-1\end{array}$ & 0.980652 & 0.965798 & 0.986909 & 2160396 & 4168783 & 1443169 & $\begin{array}{c}\text { BFGS (Quasi- } \\
\text { Newton) 17 }\end{array}$ & $\begin{array}{c}\text { Sum of } \\
\text { squares }\end{array}$ & Tanh & Exponential \\
\hline $\begin{array}{l}\text { MLP } \\
30-3-1\end{array}$ & 0.981757 & 0.966519 & 0.985911 & 2004951 & 4275632 & 1625783 & $\begin{array}{c}\text { BFGS (Quasi- } \\
\text { Newton) 32 }\end{array}$ & $\begin{array}{c}\text { Sum of } \\
\text { squares }\end{array}$ & Tanh & Exponential \\
\hline
\end{tabular}

Source: Own processing.

For this part of experiment, there are 30 neurons in the output layer. The table shows that neural networks with 3 and 4 neurons in the hidden layer were retained. The hyperbolic tangent function is used by neural networks to activate the hidden layer. The output neuron layer is activated by the exponential function and the identity function. Of course, the performance of neural networks is important. It is expressed by a correlation coefficient. The correlation coefficient is very high for all data sets and all networks, each time above 0.96 which is a high level of direct dependence. This parameter clearly shows that the retained neural structures constitute a highly credible model of real time series, thus being able to truly predict future observations. The sum of least squares was used to establish the error rate. In this case too, the error is not significant and good-quality forecasting of time series can be expected. Figure 6 provides a comparison of the actual course of time series and equalized times series.

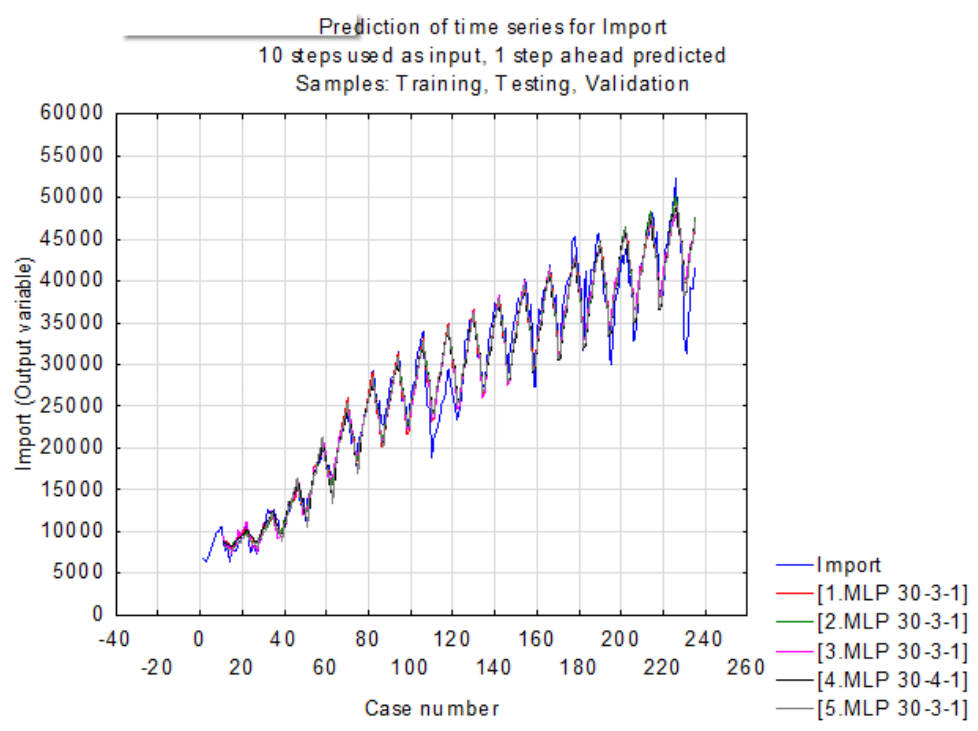

Fig. 6. Equalized time series of networks retained from Experiment 3

Source: Own processing. 
It is obvious from Figure 6 that all equalized times series are able to copy fairly well the course of actual US import from China and moreover, the course of all equalized time series is very similar. Neural networks are able to capture the trend as well as seasonal fluctuations.

Also in the case of 10-month lag of time series, we will address future predictions of the variable under review. We will predict the US import from China in the period of August 2019 to December 2020. The details are shown in Table 7.

Table 7. Forecast for the period of August 2019 to January 2020 by networks retained from Experiment 3

\begin{tabular}{|l|r|r|r|r|r|}
\hline \multicolumn{1}{|c|}{ Date } & MLP 30-3-1 & MLP 30-3-1 & MLP 30-3-1 & MLP 30-4-1 & MLP 30-3-1 \\
\hline August 31, 2019 & 47628.33 & 49720.39 & 47464.98 & 48814.61 & 48596.98 \\
\hline September 30, 2019 & 48837.86 & 51284.26 & 48327.02 & 49750.97 & 49389.40 \\
\hline October 31, 2019 & 49959.95 & 52297.62 & 49022.30 & 50807.19 & 51060.75 \\
\hline November 30, 2019 & 50449.75 & 50352.74 & 47706.31 & 48416.92 & 50686.28 \\
\hline December 31, 2019 & 46867.24 & 48109.86 & 46878.11 & 47624.49 & 48046.89 \\
\hline January 31, 2020 & 46041.69 & 45989.38 & 46020.18 & 46861.19 & 46301.59 \\
\hline February 29, 2020 & 42208.11 & 41025.14 & 42797.71 & 41273.91 & 40974.64 \\
\hline March 31, 2020 & 42495.83 & 41372.79 & 43634.20 & 42142.19 & 42009.30 \\
\hline April 30, 2020 & 45026.20 & 44732.08 & 45831.48 & 45485.90 & 45045.58 \\
\hline May 31, 2020 & 46921.96 & 47618.64 & 47618.49 & 48232.82 & 47757.49 \\
\hline June 30, 2020 & 47976.45 & 48794.48 & 48409.38 & 49450.13 & 49140.73 \\
\hline July 31, 2020 & 49584.24 & 52005.43 & 49645.76 & 51801.52 & 52358.90 \\
\hline August 31, 2020 & 51077.79 & 54756.44 & 50636.59 & 53605.07 & 54543.17 \\
\hline September 30, 2020 & 52299.32 & 56770.97 & 51352.24 & 54625.63 & 55204.93 \\
\hline October 31, 2020 & 53389.33 & 58254.67 & 51888.43 & 55617.13 & 57312.10 \\
\hline November 30, 2020 & 54033.93 & 56582.64 & 51327.16 & 54278.13 & 59088.72 \\
\hline December 31, 2020 & 51211.21 & 54610.00 & 51015.99 & 53986.72 & 56393.04 \\
\hline
\end{tabular}

Source: Own processing.

As previously mentioned, the forecasts are very similar. It is warranted to a certain extent by the chart in Figure 7.

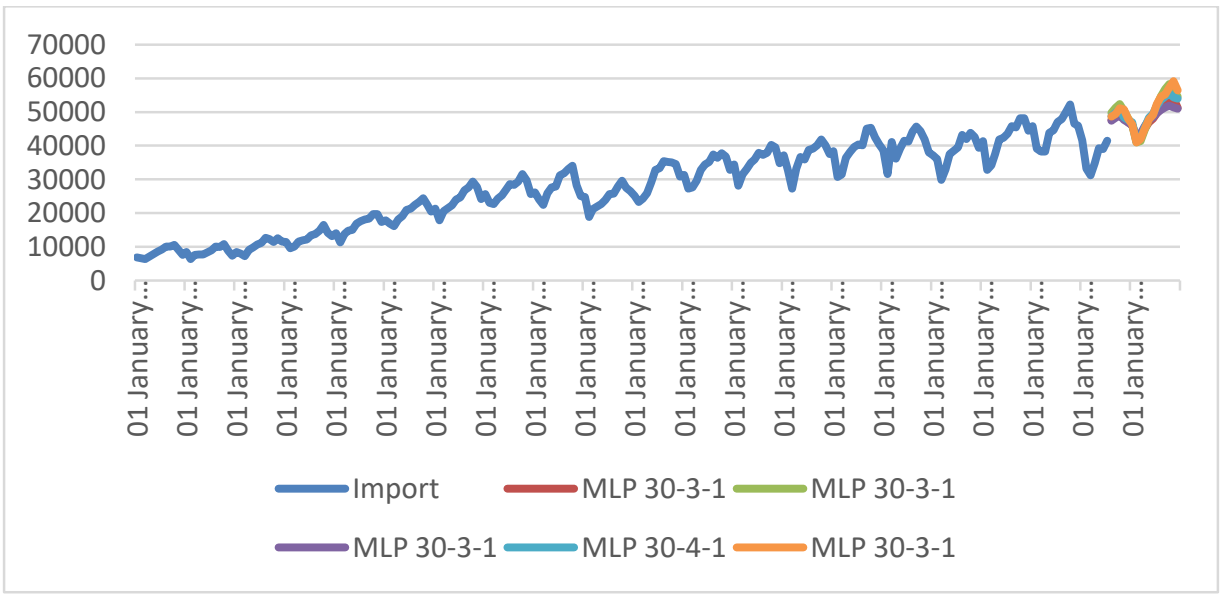

Fig. 7. Time series and forecasting trend by networks retained from Experiment 3

Source: Own processing. 
If the actual trend of US import from China is compared to the expected time trend of the variable predicted by using the artificial neural networks retained from Experiment 3, we conclude (mainly considering the statistics table in Schedule 2) that 5. MLP 30-3-1 network provides the best prediction of future observations.

\subsection{Discussion of results}

Three experiments were conducted in research. The intention was to examine the trend of time series represented by US import from China. In particular, we examined how multilayer perceptron networks are able to equalize time series. In each experiment, 10,000 artificial neural networks were generated. Five best structures were retained from each experiment. All but one from Experiment 1 which clearly suffered from overfitting can be used for prediction of the future US import from China. In each case, the performance of networks was high and the error rate was fairly low. We defined the best network in each experiment and conducted further comparison of this network (more details in Table 8).

Table 8. Comparison of the most successful neural structures from all experiments

\begin{tabular}{|l|r|r|r|}
\hline \multicolumn{1}{|c|}{ Date } & Experiment 1 & Experiment 2 & Experiment 3 \\
\cline { 2 - 4 } & 4.MLP 3-9-1 & 5.MLP 15-4-1 & MLP 30-3-1 \\
\hline August 31, 2019 & 46645.94 & 47797.37 & 48596.98 \\
\hline September 30, 2019 & 47420.89 & 49334.92 & 49389.40 \\
\hline October 31, 2019 & 47654.44 & 50106.41 & 51060.75 \\
\hline November 30, 2019 & 47142.82 & 50462.89 & 50686.28 \\
\hline December 31, 2019 & 45928.15 & 50694.26 & 48046.89 \\
\hline January 31, 2020 & 45578.78 & 50964.55 & 46301.59 \\
\hline February 29, 2020 & 35745.96 & 45836.01 & 40974.64 \\
\hline March 31, 2020 & 38287.74 & 45078.61 & 42009.30 \\
\hline April 30, 2020 & 41572.72 & 43639.14 & 45045.58 \\
\hline May 31, 2020 & 44750.52 & 43976.81 & 47757.49 \\
\hline June 30, 2020 & 46893.48 & 44301.28 & 49140.73 \\
\hline July 31, 2020 & 47835.32 & 47687.89 & 52358.90 \\
\hline August 31, 2020 & 48096.97 & 51304.98 & 54543.17 \\
\hline September 30, 2020 & 48127.50 & 54268.33 & 55204.93 \\
\hline October 31, 2020 & 48126.36 & 56228.17 & 57312.10 \\
\hline November 30, 2020 & 47998.17 & 57365.47 & 59088.72 \\
\hline December 31, 2020 & 47393.27 & 57994.40 & 56393.04 \\
\hline
\end{tabular}

Source: Own processing.

The differences between neural networks are already presented in Table 8. Although not visible at first sight, the differences mainly between networks selected from Experiment 2 and 3 are not significant. This situation is even better illustrated in Figure 8. 


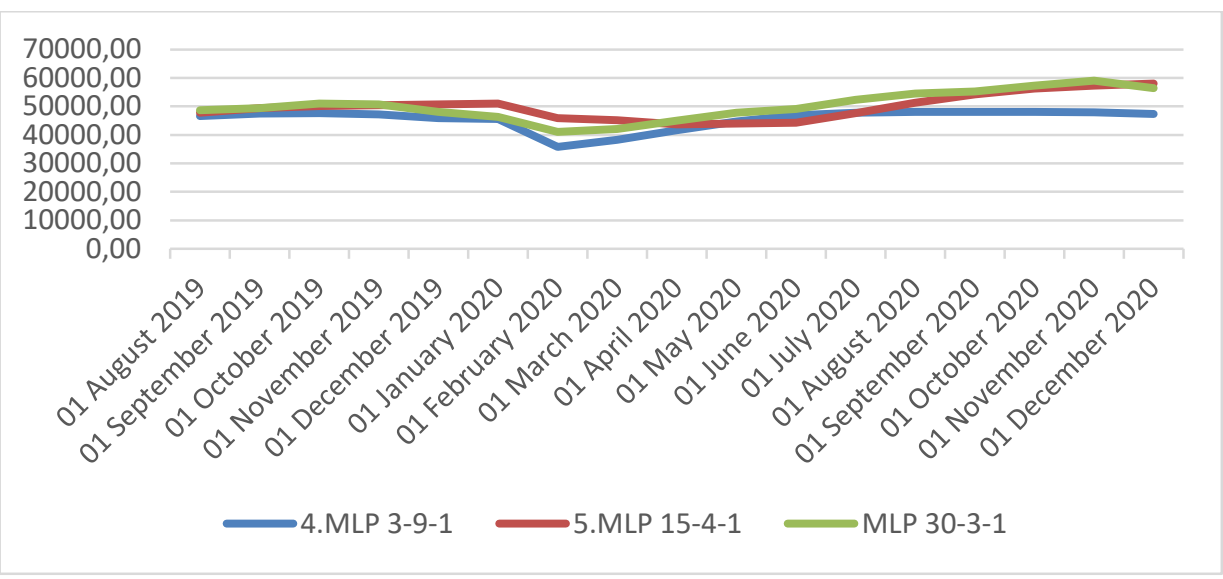

Fig. 8. Comparison of the most successful neural structures from all experiments Source: Own processing.

A very similar course of all selected neural structures is apparent from the figure. Some differences, although not fundamental are identified in February 2020 and November and December of the same year. However, it should be noted that a very similar output is presented by the networks from Experiment 2 and 3.

\section{Conclusion}

The objective of this paper was to forecast the import of the United States of America from the People's Republic of China using machine learning techniques. It can be concluded that the objective of this paper was achieved:

1. It appears as if multilayer perceptron networks will be a great forecasting tool for US import from China.

2. MLP networks are able to cover both the trend of the entire time series and its seasonal fluctuations.

3. Time-series lag must be applied. Acceptable results are established for 5- and 10-month lag of time series.

4. Mutual sanctions of both countries did not have a significant impact on forecasting using machine learning.

Further research should solely be directed to an experiment that would provide information which lag of time series would be the most appropriate for this type of task and this specific variable.

\section{References}

1. Z. Rowland, P. Šuleř, M. Vochozka, Comparison of neural networks and regression time series in estimating the Czech Republic and China trade balance. SHS Web of Conferences: Innovative Economic Symposium 2018 - Milestones and Trends of the World Economy, 61 (2019)

2. H. Yaping, S. Pengfei, M. Vochozka, Pollution caused by finance and the relative policy analysis in China. Energy \& Environment, 28(7), 808-823 (2017) 
3. M. Vochozka, J. Vrbka, Estimation of the development of the Euro to Chinese Yuan exchange rate using artificial neural networks. SHS Web of Conferences: Innovative Economic Symposium 2018 - Milestones and Trends of World Economy, 61 (2019)

4. Understanding the US - China Trade Relationship: Prepared fot the US - China Business Council by Oxford Economics. The US - China Business Council: Understanding the US-China Trade Relationship [online], Available at: https://www.uschina.org/sites/default/files/Oxford\%20Economics\%20US\%20Jobs\%20 and\%20China\%20Trade\%20Report.pdf (2017)

5. M. Chossudovsky, Trump's Trade War with China: Imagine What Would Happen if China Decided to Impose Economic Sanctions on the USA? Global Research: Centre for Research on Globalization [online], Available at: https://www.globalresearch.ca/imagine-what-would-happen-if-china-decided-toimpose-economic-sanctions-on-the-usa-2/5598941 (2017)

6. M. Vochozka, J. Horák, P. Šuleř, Equalizing seasonal time series using artificial neural networks in predicting the Euro-Yuan exchange rate. Journal of Risk and Financial Management, 12(2) (2019)

7. V.V. Mikheev, S.A. Lukonin, China - USA: multiple vector OF "trade war". World Economy and International Relations, 63(5), 57-66 (2019)

8. J. Vrbka, Z. Rowland, P. Šuleř, Comparison of neural networks and regression time series in estimating the development of the EU and the PRC trade balance. SHS Web of Conferences: Innovative Economic Symposium 2018 - Milestones and Trends of World Economy, 61 (2019)

9. L.D. Qiu, C. Zhan, X. Wei, An analysis of the China - US trade war through the lens of the trade literature. Economic and Political Studies, 7(2), 148-168 (2019)

10. $\mathrm{M} . \mathrm{Yu}$, Introduction to the Special Issue on Understanding the Current China-U.S. 'Trade War'. China Economic Journal, 12(2), 97-99 (2019)

11. E.L.C. Lai, The US - China trade war, the American public opinions and its effects on China. Economic and Political Studies, 7(2), 169-184 (2019)

12. K. Itakura, Evaluating the Impact of the US - China Trade War. Asian Economic Policy Review (2019)

13. T.T.L. Chong, X. Li, Understanding the China - US trade war: causes, economic impact, and the worst - case scenario. Economic and Political Studies, 7(2), 185-202 (2019)

14. V. Machová, J. Mareček, Estimation of the development of Czech Koruna to Chinese Yuan exchange rate using artificial neural networks. SHS Web of Conferences: Innovative Economic Symposium 2018 - Milestones and Trends of World Economy, 61 (2019)

15. Y. Li, US Economic Sanctions Against China: A Cultural Explanation of Sanction Effectiveness. Asian Perspective, 38(2), 311-335 (2014)

16. J. Yang, H. Askari, J. Forrer, H. Teegen, US Economic Sanctions Against China: Who Gets Hurt? World Economy, 27(7), 1047-1081 (2004)

17. China vows to impose sanctions on US firms supplying Taiwan military. The Guardian [online], Available at: https://www.theguardian.com/world/2019/jul/12/china-taiwansanctions-us-firms-military-sales (2019)

18. S.V. Nozdrev, China in Global Financial System. World Economy and International Relations, 60(10), 29-40 (2016) 
19. B. Seyoum, US foreign trade zones and import intensity examining determinants of import intensity in US foreign trade zones. European Business Review, 29(1), 103-122 (2017)

20. A. Pandey, US - China trade war: Huawei's loss is Samsung's gain. DW: Made for minds [online], Available at: https://www.dw.com/en/us-china-trade-war-huaweis-lossis-samsungs-gain/a-48814477(2019)

21. T. Besedeš, T.J. Prusa, The Hazardous Effects of Antidumping. Economic Inquiry, 55(1), 9-30 (2017)

22. H. Lee, Estimating the Protection Effects of Antidumping Duties. Journal of Korea Trade, 13(3), 1-23 (2009)

23. S. Park, The Trade Depressing and Trade Diversion Effects of Antidumping Actions: The Case of China. China Economic Review, 20(3), 542-548 (2009)

24. N. Choi, Did Anti-dumping Duties Really Restrict Import? Empirical Evidence from the US, the EU, China, and India. East Asian Economic Review, 21(1), 3-27 (2017)

25. L. Yu, S. Wang, K.K. Lai, Forecasting China's Foreign Trade Volume with a KernelBased Hybrid Econometric-Ai Ensemble Learning Approach. Journal of Systems Science and Complexity, 21(1), 1-19 (2008)

26. J. Deggans, T. Krulický, M. Kováčová, K. Valášková, M. Polliak, Cognitively enhanced products, output growth and labor market changes: Will artificial intelligence replace workers by automating their jobs? Economics, Management, and Financial Markets, 14(1), 38-43 (2019)

27. J. Weijin, X. Yuhui, A novel method for nonlinear time series forecasting of time delay neural network. Wuhan University Journal of Natural Sciences, 11(5), 13571361 (2006)

28. World Bank [online], Available at: https://data.worldbank.org/indicator/TM.TAX.MRCH.WM.AR.ZS?end=2017\&locatio $\underline{\mathrm{ns}}=\mathrm{CN}-\mathrm{US} \& \mathrm{start}=2014$ (2019) 


\section{Schedule 1}

Basic statistics of equalized time series - 1-month lag

\begin{tabular}{|c|c|c|c|c|c|}
\hline Statistics & $\begin{array}{c}\text { 1.MLP } \\
3-7-1 \\
\end{array}$ & $\begin{array}{c}\text { 2.MLP } \\
3-8-1 \\
\end{array}$ & $\begin{array}{c}\text { 3.MLP } \\
3-4-1 \\
\end{array}$ & $\begin{array}{c}\text { 4.MLP } \\
3-9-1 \\
\end{array}$ & $\begin{array}{c}\text { 5.MLP } \\
3-4-1 \\
\end{array}$ \\
\hline \begin{tabular}{|l|} 
Minimum forecast (Training) \\
\end{tabular} & 7354.37 & 6559.94 & 8142.94 & 4119.17 & 7193.36 \\
\hline Maximum forecast (Training) & 47396.03 & 48014.80 & 48288.31 & 46169.46 & 48594.69 \\
\hline Minimum forecast (Testing) & 7254.62 & 7045.62 & 8029.47 & 3015.71 & 7079.77 \\
\hline Maximum forecast (Testing) & 48674.80 & 49154.72 & 49613.73 & 47021.13 & 49544.61 \\
\hline Minimum forecast (Validation & 7478.22 & 7840.43 & 8273.81 & 5681.94 & 7347.37 \\
\hline Maximum forecast (Valida & 48516.18 & 48278.85 & 48569.99 & 46786.56 & 49352.04 \\
\hline Minimum residues (Training) & -4712.82 & -5176.38 & -6518.51 & -5066.37 & -6957.79 \\
\hline Maximum residues (Training) & 7330.04 & 7387.11 & 7219.56 & 7026.74 & 8087.28 \\
\hline $\mathrm{n}$ residues $(\mathrm{T}$ & -4910.74 & -3967.62 & -7436.32 & -4426.25 & -6291.87 \\
\hline Maximum residues (Tes & 4514.17 & 3379.49 & 3484.47 & 5181.17 & 4175.70 \\
\hline Minimum residues (Validation) & -2585.83 & -2612.07 & -4704.98 & -3275.40 & -4326.75 \\
\hline Maximum residues (Validation) & 4740.17 & 5076.42 & 2623.07 & 4572.21 & 3476.45 \\
\hline Minimum standard residues ( $\mathrm{T}$ & -4.13 & -4.49 & -4.71 & -4.81 & -4.58 \\
\hline Maximum standard residues (T & 6.42 & 6.40 & 5.22 & 6.67 & 5.32 \\
\hline Minimum standard residues (Testing) & -3.58 & -3.49 & -4.01 & -2.94 & -3.45 \\
\hline Maximum standard residues (Testing) & 3.29 & 2.97 & 1.88 & 3.45 & 2.29 \\
\hline Minimum standard residues (Validatio & -2.20 & -2.20 & -4.00 & -2.62 & -3.48 \\
\hline Maximum standard re & 4.03 & 4.28 & 2.23 & 3.65 & 2.80 \\
\hline
\end{tabular}

\section{Schedule 2}

\section{Basic statistics of equalized time series - 5-month lag}

\begin{tabular}{|c|c|c|c|c|c|}
\hline Statistics & $\begin{array}{l}1 . \mathrm{MLP} \\
15-3-1\end{array}$ & $\begin{array}{l}\text { 2.MLP } \\
15-7-1\end{array}$ & $\begin{array}{l}\text { 3.MLP } \\
15-7-1\end{array}$ & $\begin{array}{l}\text { 4.MLP } \\
15-10-1\end{array}$ & $\begin{array}{l}5 . M L P \\
15-4-1\end{array}$ \\
\hline Minimum forecast (Training) & 5752.93 & 7952.83 & 8335.37 & 8239.21 & 8144.24 \\
\hline Maximum forecast (Training) & 48664.89 & 47750.67 & 47773.06 & 47580.68 & 48129.11 \\
\hline Minimum forecast (Testing) & 9259.27 & 9226.17 & 9230.93 & 9160.76 & 9370.74 \\
\hline Maximum forecast (Testing) & 48955.84 & 49144.91 & 48949.81 & 50189.47 & 48249.50 \\
\hline Minimum forecast (Validation) & 11050.71 & 9440.66 & 9456.50 & 9598.51 & 9230.38 \\
\hline Maximum forecast (Validation) & 48266.83 & 47781.93 & 47405.82 & 49350.75 & 47896.93 \\
\hline Minimum residues (Training) & -7132.39 & -4323.94 & -4579.37 & -4409.89 & -7308.98 \\
\hline Maximum residues (Training) & 7907.11 & 8082.84 & 7739.53 & 7788.84 & 8020.51 \\
\hline Minimum residues (1 & -8006.76 & -3966.38 & -4111.01 & -4183.43 & -9100.39 \\
\hline Maximum residues (Testing) & 3246.46 & 3928.01 & 3951.86 & 4231.92 & 3952.80 \\
\hline Minimum residues (Validation) & -4409.00 & -2874.81 & -2937.65 & -4393.50 & -4758.93 \\
\hline Maximum residues (Validation) & 2948.14 & 4569.47 & 3537.80 & 4950.74 & 3961.35 \\
\hline Minimum standard residues (Tra & -4.98 & -4.03 & -3.88 & -3.73 & -4.74 \\
\hline Maximum standard residues (Training) & 5.52 & 7.53 & 6.56 & 6.59 & 5.20 \\
\hline Minimum standard residues (Testing) & -4.21 & -2.80 & -2.70 & -2.74 & -4.33 \\
\hline Maximum standard residues (Testing) & 1.71 & 2.77 & 2.60 & 2.77 & 1.88 \\
\hline Minimum standard residues $(\mathrm{Val}$ & -3.47 & -2.53 & -2.43 & -3.43 & -3.62 \\
\hline Maximum standard residues (Validation) & 2.32 & 4.02 & 2.93 & 3.87 & 3.02 \\
\hline
\end{tabular}


Schedule 3

Basic statistics of equalized time series - 10-month lag

\begin{tabular}{|c|c|c|c|c|c|}
\hline Statistics & $\begin{array}{l}1 . M L P \\
30-3-1\end{array}$ & $\begin{array}{l}\text { 2.MLP } \\
30-3-1\end{array}$ & $\begin{array}{l}3 . M L P \\
30-3-1\end{array}$ & $\begin{array}{l}\text { 4.MLP } \\
30-4-1\end{array}$ & $\begin{array}{l}\text { 5.MLP } \\
30-3-1\end{array}$ \\
\hline Minimum forecast (Training) & 8137.69 & 8162.69 & 7379.79 & 8221.65 & 7621.39 \\
\hline Maximum forecast (Training) & 48644.28 & 48255.74 & 46387.41 & 47328.36 & 48550.17 \\
\hline Minimum forecast (Testing) & 9292.58 & 9020.55 & 8870.28 & 9523.50 & 8826.83 \\
\hline Maximum forecast (Testing) & 48575.03 & 50304.35 & 48013.80 & 49276.72 & 49421.77 \\
\hline Minimum forecast (Validation) & 9810.03 & 9189.25 & 10003.05 & 9621.15 & 9200.18 \\
\hline Maximum forecast (Validation) & 47526.94 & 49311.92 & 47293.30 & 48260.61 & 47858.95 \\
\hline Minimum residues (Training) & -6506.02 & -6428.79 & -6169.27 & -6466.52 & -6139.14 \\
\hline Maximum residues (Training) & 7902.86 & 8700.19 & 7788.67 & 8921.58 & 8463.54 \\
\hline Minimum residues (Testing) & -8618.38 & -7617.52 & -9319.86 & -7496.30 & -7656.74 \\
\hline Maximum residues (Testing) & 3627.27 & 3661.09 & 4188.50 & 3431.46 & 3573.96 \\
\hline Minimum residues (Validation) & -4560.79 & -5080.26 & -4431.97 & -4071.65 & -4657.13 \\
\hline Maximum residues (Validation) & 2495.61 & 3452.72 & 2781.95 & 3265.68 & 2884.09 \\
\hline Minimum standard residues (Training) & -4.75 & -4.42 & -4.36 & -4.40 & -4.34 \\
\hline Maximum standard residues (Training) & 5.77 & 5.98 & 5.51 & 6.07 & 5.98 \\
\hline Minimum standard residues (Testing) & -3.90 & -3.72 & -4.17 & -3.67 & -3.70 \\
\hline Maximum standard residues (Testing) & 1.64 & 1.79 & 1.87 & 1.68 & 1.73 \\
\hline Minimum standard residues (Valic & -3.87 & -4.12 & -3.60 & -3.39 & -3.65 \\
\hline Maximum standard residues (Validation) & 2.12 & 2.80 & 2.26 & 2.72 & 2.26 \\
\hline
\end{tabular}

